\title{
Moontlike nuwe lig op die Paulus-gemeentes
}

\section{'n Nuut-ontdekte manuskrip van Philodemus word ontgin}

Fika J. van Rensburg

Departement Ou en Nuwe Testament

Potchefstroomse Universiteit vir $\mathrm{CHO}$

POTCHEFSTROOM

Prof. Fika J. ian Rensburg werk die afgelope paar jaar mee aan '" imternasionale projek om '" mumtontdekle Griekse manuskrip uit die eerste een vir naworsing toeganklik te maak. Hy hel gedurende November 1995 as deel van die projek die jaarvergadering van die Society of Biblical literature in Philadelphia in die VSA bygew(x)m. Hy is fillansieel ondersteun deur die Raad vir Geesieswetenskaplike Navorsing, die PU vir CHO en die Teologiese Skool Potchefstroom. In die onderstaande mededeling gee hy oorsigtelik inliging oor die projek in die algemeen.

\section{Die Philodemus-projek}

Die jaarvergadering van die Society of Biblical literature (SBL) het plaasgevind van 18-21 November 1995 in Philadelphia in die VSA. Een van die subgroepe van die SBL is die Hellenistic Moral Philosophy and Early Christianity Group, waarvan ek lid is. Die bestuur van hierdie groep het my in 1992 genooi om deel te wees van die Philodernus-projek

Tydens die 1992-jaarvergadering van die SBL het ons (die Hellenistıc Moral Philosophy and Early (hristianity (Group) 'n verkennende seminaar oor Philodemus (c. 110-35 v.C.) se werk On lirank Crilicism gehad Dit was onmiddellik duidelik dat hierdie werk van die uiterste belang is vir die konstruksie van baie fasette van die sosio-listoriese konteks van die Griekse Nuwe Testament. Die beskikbare teks, herontdek in 1752-1754 nadat dit as deel van 'n biblioteek in 79 n.C. by Vesuvius onder lawa begrawe is, is egter fragmentaries ell problematies. Die oorspronklike papirusmanuskripte is verkool, en die middeldeel van die papirusrolle het verkrummel, sodat daardie deel van die teks vernietig is Verder is daar geen vertaling in ' $n$ moderne taal beskikbaar nie, en Philodemus se Grieks is uitsonderlik moeilik om te lees 


\section{Die navorsingspan en werkwyse}

Die bestuur van die Hellenistic Moral Philosophy and Early Christianity (iroup het gevolglik besluit om ' $n$ internasionale en interdissiplinêre navorsingspan van 24 persone (uit Kanada, Denemarke, Ysland, die VSA, Brittanje, Italië en RSA) saam te stel om 'n nuwe teksuitgawe voor te berei en ook 'n Engelse vertaling beskikbaar te stel. Alexander Olivieri se teksuitgawe (die enigste wat tot dusver bestaan, en wat dateer uit 1914) is in 24 dele verdeel, en elke lid van die navorsingspan moes een deel vir die vergadering van 1993 voorberei. (Ek was self verantwoordelik vir Fragmente 8-15.) Die projekleier, John T. Fitzgerald, het die verskillende dele gekonsolideer en dit is tydens ons 1993-vergadering in Washington, $\mathrm{DC}$ voorgelê. $\mathrm{Na}$ afloop van die werksessie is ' $\mathrm{n}$ paneel van vyf lede aangewys om die vertaling en notas wat die navorsingspan geproduseer het, te finaliseer.

Hierdie nuwe manuskrip is in September aan al die lede van die navorsingspan beskikbaar gestel, en elke lid se taak was (in die woorde van die leier van die span)

... to look over their translation and notes, with each of us focusing our attention on the portion of the text that we had worked on for the 1993 Washington meeting. Once we have done that, we will need to send whatever comments and observations we have to the five member translation team prior to the Philadelphia meeting. At the session in Philadelphia we shall discuss Philodemus' text and the team's translation.

Presies dit het toe tydens die 1995-vergadering gebeur.

\section{Enkele belangwekkende resultate tot dusver}

\subsection{Die voorbereiding van 'n teksedisie en vertaling}

Dr. Johan Thom (van die Universiteit van Stellenbosch) se taak was om in die volgende jaar die Griekse teks met tekskritiese apparaat voor te berei, en dr. David Konstan (Brown University, VSA) om die vertaling verder te verfyn.

Die voorbereiding van 'n teksedisie lewer baie probleme. Dit blyk dat baie amendasies van die Olivieri-teks noodsaaklik is, onder andere omdat sommige vroeë Italiaanse uitgawes van die teks nie deur Olivieri genoteer is nie Omdat die oorspronklike manuskrip erg beskadig is deur die lawa, is groot dele van sinne nie leesbaar nie en is dit nie altyd moontlik om dié wat wel leesbaar is, sintakties te plaas nie. Die oorspronklike manuskrip is tans $m$ die sorg van Marcello Gigante, 'n Italiaanse geleerde, en daar is nie toegang tot die manuskrip nie. Die werk moet dus van afskrifte af gedoen word, wat die taak verder bemoeilik. 
'n Verdere probleem is dat baie van die Griekse woorde nie in standaardwoordeboeke voorkom nie, of dat die betekenisdefinisies nie in die konteks pas nie. Verder is dit ook nie altyd duidelik hoe die verskillende fragmente met mekaar saamhang nie.

\subsection{Skedulering van aktiwiteite vir die volgende jaar}

Die opgedateerde weergawe van die vertaling en teks word teen die einde van April 1996 by al die lede van die span gesirkuleer. Die spanlede het as opdrag om 'n Griekse en Engelse indeks voor te berei en om 'n Inleiding te skryf. Die beplanning is dat die finale manuskrip teen die einde van Augustus 1996 by Scholar's Press ingelewer moet word.

\section{Moontlike insigte deur dié "nuwe" venster}

Die navorsing het belangrike implikasies, veral vir die konstruksie van baie fasette van die Pauliniese gemeentes, onder andere vanweë die opmerklike ooreenkomste (en natuurlik verskille) wat daar tussen die Pauliniese gemeentes aan die een kant en die Epikureense gemeenskappe aan die ander kant bestaan het. Philodemus se On Frank Criticisin kan ontgin word oor die interne dinamikas van 'n Epikureense gemeenskap, en dit kan op sy beurt die Pauliniese gemeentes in groter sosio-historiese reliëf plaas.

Fasette van die funksionering van so 'n hegte gemeenskap waaroor daar meerdere inligting na vore kom, is onder andere hoe verskille ten opsigte van geslag en sosiale status gehanteer is, hoe onderlinge morele opvoeding en dissiplinering plaasgevind het, hoe nuwelinge tot die gemeenskap toegevoeg is, die openheid wat daar by die groepe was, en die reguit wyse waarop persone mekaar onderling vermaan het.

\section{Ten slotte}

Dit stem 'n mens tot groot dankbaarheid om te ervaar hoedat ons hemelse Vader beskik het dat die "natuurramp" van die uitbarsting van Vesuvius in die eerste eeu van ons jaartelling hierdie skat val ınligtıng oor die eerste eeu behoue laat bly het. Wonderlik ook is sy genade dat daar internasionale kundigheid is oor die Griekse taal en teksrekonstruksie on die verkoolde papirusrolle verder te ontsyfer. So kom daar mettertyd nog 'n bron beskikbaar om nog groter insig te kry in die wêreld waarin God die Nuwe-Testamentiese boeke laat ontstaan het. 
